\title{
Prof. Dr. György Lichtenberger (1944-2009), Budapest, Hungary
}

\author{
J. A. Werner · F. G. Dikkers · H. E. Eckel · J. Olofsson
}

Published online: 10 July 2009

(C) Springer-Verlag 2009

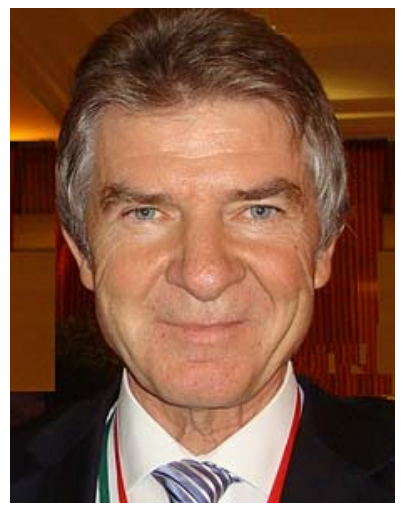

Hungarian Academy of Science in 1987 and won the candidate title of the medical science. Starting in 1988, György Lichtenberger guided and formed the otorhinolaryngology department from 1988 in the wake of Aurél Réthi. He even served as the hospital director for some years.

In the broad spectrum of otorhinolaryngology, György Lichtenberger focussed, rather early, his interest and activity on laryngeal and tracheal diseases, certainly stimulated by his worldwide known predecessor Réthi. The main fields of György Lichtenberger's interest were laryngeal and laryngotracheal stenoses. Besides his clinical work, he carried out experiments on laboratory animals, which enabled him to develop several procedures for microsurgical man-

On 27 May 2009, the world otorhinolaryngology community suffered the abrupt and premature loss of an exceptional leader, Prof. György Lichtenberger.

György Lichtenberger obtained his medical degree in 1974 at the Medical University of Pécs, Hungary. Following his studies, he started his professional career in the same year in Rókus Hospital. He defended his dissertation on the

\section{J. A. Werner $(\bowtie)$}

Department of Otolaryngology, Head and Neck Surgery,

University of Marburg, Deutschhausstr. 3,

35037 Marburg, Germany

e-mail: wernerj@med.uni-marburg.de

\section{F. G. Dikkers}

Department of Otorhinolaryngology,

University Medical Center Groningen,

University of Groningen, Groningen, The Netherlands

H. E. Eckel

Department of Otolaryngology, Klagenfurt, Austria

J. Olofsson

Department of Otolaryngology,

Haukeland University Hospital, Bergen, Norway agement of certain types of laryngotracheal stenosis. He created and perfected continuously the endo-extra laryngeal lateralization method, hallmarking his name. He himself developed some devices, one of which is the needle carrier instrument. Besides his best-known innovation, a number of additional practical equipments and patents are associated with his name. He was an inventor, and noticed the opportunities residing in the objects: a rare condition for a doctor. He developed six new operative procedures, for which he was awarded the "Honthy Hanna Prize" (a prize meant for doctors, who enrich medical science with inventions and new procedures). He valiantly took on hopeless cases; a lot of patients may thank him for a life without cannula, the repossession of sound and the improvement in their quality of life. These methods have been introduced at many clinics in Europe and the USA, as well as being included in chapters of German and American textbooks on Otorhinolaryngology, Head and Neck Surgery.

In 1996, György Lichtenberger was promoted to professorship at "Albert Szentgyörgyi" University of Szeged, Hungary. He participated in the faculty of continuing education courses in otorhinolaryngology. 
As an invited lecturer, he took part in a number of conferences and instructional courses, from India through the USA until Europe. Nevertheless, he attained the largest appreciation in the German-speaking area, due to his distinguished language knowledge. A high number of internationally acknowledged doctors of laryngology cultivated a tight friendship with him. His last prestigious accolade was in 2007, to deliver the Semon Lecture of the University in London at the Royal Society of Medicine. He was the first Hungarian otorhinolaryngologist who received this acknowledgement. His publication list reached nearly 100 papers, half of them written in English or German. However, besides his foreign successes he did not neglect his homeland. He organized an ELS workshop in Budapest and conducted professional development courses in the Rókus Hospital. Supporting Hungarian doctors, who lived over the border, was close to his heart. For this respected work, he won the Hungarian Heritage prize in 2007.

György Lichtenberger was a member of the European Laryngological Society and of the International Association of Phonosurgeons. He was honorary member of the German, Slovak, Austrian, Polish Societies of ORL-HNS and corresponding member of the American Academy of Otolaryngology, Head and Neck Surgery, American Laryngological Association, American Broncho-Esophageal Association and American Head and Neck Society.
With György Lichtenberger, we also lost a very committed member of the editorial board of the European Archives of Oto-Rhino-Laryngology and Head and Neck.

György Lichtenberger was able to perform all of the listed activities, and many others that were not even mentioned, simultaneously with his professional work at the Rókus Hospital of Budapest, Hungary, where, without any doubt, he spent his most beautiful and most fertile period of his life.

The Rókus Hospital was closed based on decisions of health-care policy, as also other hospitals in Budapest. So György Lichtenberger had to focus his energies on a reorganization. On 1 July 2007, he was elected Chairman of the Department of Otorhinolaryngology, Head and Neck Surgery, of the State Health Centre at Budapest, Hungary. This most difficult part of his life developed parallel to the severe disease of his beloved wife, whom he lost in 2008 . György Lichtenberger did not overcome this loss.

With György Lichtenberger, an excellent doctor and a scientist passed away. The international ENT community mourns the loss of an exemplary link between Hungary and many other European and extra-European countries. We personally have lost a very true friend, whom we will never forget for his outstanding integrity, reliability and adorable character. 